\title{
Review \\ Plant-Based Vaccines in Combat against Coronavirus Diseases
}

\author{
Benita Ortega-Berlanga * and Tomasz Pniewski
}

Institute of Plant Genetics, Polish Academy of Sciences, Strzeszyńska 34, 60-479 Poznań, Poland; tpni@igr.poznan.pl

* Correspondence: bort@igr.poznan.pl

Citation: Ortega-Berlanga, B.; Pniewski, T. Plant-Based Vaccines in Combat against Coronavirus

Diseases. Vaccines 2022, 10, 138 https://doi.org/10.3390/ vaccines 10020138

Academic Editor: Sankar Basu

Received: 4 December 2021

Accepted: 14 January 2022

Published: 18 January 2022

Publisher's Note: MDPI stays neutral with regard to jurisdictional claims in published maps and institutional affiliations.

Copyright: (c) 2022 by the authors. Licensee MDPI, Basel, Switzerland. This article is an open access article distributed under the terms and conditions of the Creative Commons Attribution (CC BY) license (https:// creativecommons.org/licenses/by/ $4.0 /)$.

\begin{abstract}
Coronavirus (CoV) diseases, including Middle East Respiratory Syndrome (MERS) and Severe Acute Respiratory Syndrome (SARS) have gained in importance worldwide, especially with the current COVID-19 pandemic caused by SARS-CoV-2. Due to the huge global demand, various types of vaccines have been developed, such as more traditional attenuated or inactivated viruses, subunit and VLP-based vaccines, as well as novel DNA and RNA vaccines. Nonetheless, emerging new COVID-19 variants are necessitating continuous research on vaccines, including these produced in plants, either via stable expression in transgenic or transplastomic plants or transient expression using viral vectors or agroinfection. Plant systems provide low cost, high scalability, safety and capacity to produce multimeric or glycosylated proteins. To date, from among CoVs antigens, spike and capsid proteins have been produced in plants, mostly using transient expression systems, at the additional advantage of rapid production. Immunogenicity of plant-produced CoVs proteins was positively evaluated after injection of purified antigens. However, this review indicates that plant-produced CoVs proteins or their carrier-fused immunodominant epitopes can be potentially applied also as mucosal vaccines, either after purification to be administered to particular membranes (nasal, bronchus mucosa) associated with the respiratory system, or as oral vaccines obtained from partly processed plant tissue.
\end{abstract}

Keywords: coronaviruses; COVID-19; MERS-CoV; SARS-CoV; biopharming; plant-based vaccines

\section{Introduction}

Coronaviruses (CoVs) are clinically relevant pathogens that infect humans, livestock, mice, birds and many other wild animals [1]. They cause localized infections in the respiratory and/or intestinal tracts, in the liver and the central nervous system of their hosts [2]. They belong to the order Nidovirales, the family Coronaviridae. Based on phylogenetic analysis, CoVs are divided into four genera: the alpha, beta, gamma, and delta coronaviruses [2]. This family of viruses has gained in clinical relevance since 2003, when a new human coronavirus (SARS-CoV-1) was responsible for Severe Acute Respiratory Syndrome (SARS). Later in 2012, a new outbreak of another coronavirus (MERS-CoV) emerged in Saudi Arabia, causing Middle East Respiratory Syndrome (MERS) [3,4]. Most recently, in December 2019 in Wuhan, the Hubei Province, China, the pathogen responsible for a mysterious pneumonia was identified as SARS-CoV-2 and defined as the causal agent of Coronavirus Disease 2019 (COVID-19) [5]. Due to the rapid spread of the virus around the world, COVID-19 was declared to be a pandemic by the World Health Organization (WHO) in March 2020. The origin of this outbreak was associated with the Wuhan Wholesale Seafood Market, where not only seafood is traded, but also exotic fauna [6]. Due to the fact that the greatest diversity of CoVs has been found in bats [7], the hypothesis has been proposed that more recent $\mathrm{CoV}$ introductions to humans were originally bat viruses that propagate to an intermediate host (e.g., the Himalayan palm civet for SARS-CoV-1 and the dromedary camel for MERS-CoV), which then exposed humans to the viruses. According to the WHO, the SARS-CoV-1 pandemic affected 8096 people while the MERS pandemic affected 2494 people, with a fatality rate of $9.19 \%$ and $34.4 \%$, respectively [8]. Until November 2021, 
emerging SARS-CoV-2 variants and successive waves of the COVID-19 pandemic have affected more than 261 million people worldwide and have caused more than 5.2 million deaths [9]. The exponential spread of SARS-CoV-2 together with the emerging outbreaks of new CoVs in recent years highlights the urgent need to develop effective therapies and vaccines against these pathogens.

\section{Genome and Structure of Coronaviruses}

CoVs are enveloped RNA viruses, ranging from 80 to $160 \mathrm{~nm}$ in diameter. Their genome is composed of non-segmented, positive-sense RNA, which contains from 27,000 to 32,000 nucleotides, and these are the largest genomes among mammalian viruses [10]. The genome of CoVs contains a $5^{\prime}$-cap structure and a $3^{\prime}$-poly-A tail; its organization is as the follows: 5'-leader-UTR-replicase-S (Spike)-E (Envelope)-M (Membrane)-N (Nucleocapsid)-3' UTR-poly (A) tail [1]. The CoV genomes usually contain at least six open reading frames (ORFs). Two-thirds of the genome comprise two overlapping ORFs: ORF1a and ORF1b. Translation of these ORFs produces two large polypeptides: ppla and pp1ab, which after undergoing co- and post-translational modifications result in 16 non-structural proteins (nsps) that play important roles in the viral replication process [11]. The rest of the genome codes four main structural proteins: spike $(\mathrm{S})$, membrane $(\mathrm{M})$, envelope $(\mathrm{E})$, and nucleocapsid $(\mathrm{N})$ proteins (Figure 1). These are essential for virion assembly and infection [12]. The $S$ protein is a very large $(\sim 150 \mathrm{kDa})$ transmembrane and highly glycosylated protein that assembles into trimers on the viral envelope, and mediates attachment and fusion to the cell host [13]. The M protein is a small ( 25-30 kDa) multispanning membrane protein, which contains a little N-terminal ectodomain and a cytoplasmic tail. It is the most abundant structural protein in the virion [14]. This protein promotes membrane curvature, gives the virion its shape and allows the connection to the nucleocapsid [1]. In turn, the E protein is a small $(\sim 8-12 \mathrm{kDa})$ hydrophobic transmembrane protein that is involved in virus assembly, release and viral pathogenesis [15]. The $\mathrm{N}$ protein $(43-50 \mathrm{kDa})$ is a phosphoprotein which contains three regions: an N-terminal domain, a RNA-binding domain and a C-terminal domain. It is the main structural component of the nucleocapsid and can bind to RNA to protect it from degradation by ribonucleases [16]. $\mathrm{N}$ is also an antagonist of interferon (IFN), thereby promoting viral replication [17]. The genome sequence of CoVs shows $58 \%$ identity on the nsp-coding region and $43 \%$ identity on the structural protein-coding region, suggesting that structural proteins are necessary in adaptation to new hosts [1].

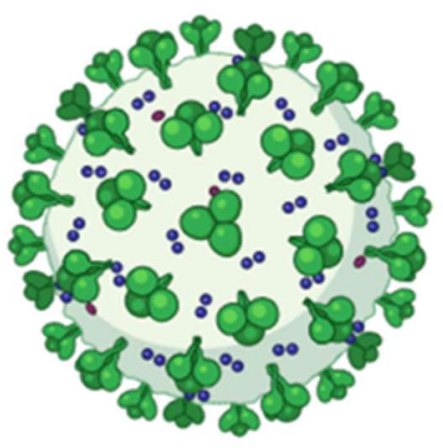

(a)

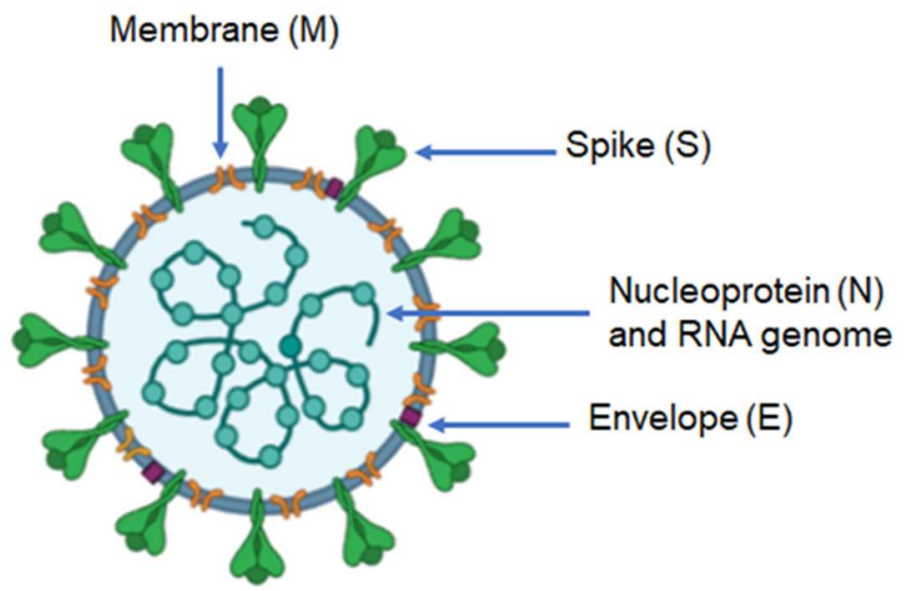

(b)

Figure 1. General structure of coronavirus. (a) 3D image; green club-shape figures: spike protein, blue dots: membrane protein, red dots: envelope protein (b) main structural proteins of CoVs. Created with BioRender.com. 


\section{Treatment and Prophylaxis against COVID-19}

The binding of the virus to its host cell through its specific receptor is a crucial step for the viral infection and therefore a promising target for the development of treatments against CoVs. Evidence from previous studies suggests that the ACE2 gene, which encodes the angiotensin-converting enzyme-2, is the host receptor for SARS-CoV-2, which is similar to SARS-CoV-1. The connection occurs through the S protein and is 10-20-fold greater compared to SARS-CoV-1, which may explain the high transmission rate of SARS-CoV-2 in humans [16,17]. ACE2 is predominantly found in epithelial cells of the lower respiratory tract as well as the enterocytes of the human intestine [17]. At present, as there is not a specific therapy against $\mathrm{CoV}$ infections, most treatments are supportive and include managing complications a patient develops, empirical antimicrobial drugs, antipyretics/analgesics, mechanical ventilation, oxygen therapy, conservative fluid supply and corticosteroids if indicated for other reasons [18]. Here, we summarize the main experimental therapeutics available for the treatment of CoVs.

Antiviral drugs: Remdesivir is a nucleotide analogue with a broad spectrum of antiviral activity against RNA viruses; it blocks the RNA-dependent RNA polymerase which inhibits the virus replication $[18,19]$. However, its effectiveness and safety have not been tested in clinical trials yet. Ribavirin is another nucleoside analogue of broad-spectrum antiviral activity which inhibits RNA synthesis. Despite studies demonstrating that this drug inhibits SARS-CoV-1, MERS-CoV, and HCoV-OC43 in vitro, tested doses were significantly higher than typical concentrations used in humans [20,21]. Lopinavir/ritonavir are used in the treatment against HIV infection. Previous studies showed a good therapeutic effect in SARS and MERS, thus these drugs have been recommended for clinical treatment of COVID-19 [22,23]. Arbidol is a broad-spectrum antiviral agent commonly used in influenza virus infections. In vitro assays have shown antiviral activity against SARS-CoV-1 and SARS-CoV-2 [24].

Antiviral peptides: previous reports have described some potential peptides against SARS-CoV-1 and SARS-CoV-2 infections, these target the S protein-ACE2 interaction and entry process [25-27]. Its main advantages are associated with specificity, affinity and low cytotoxicity; however, one of its disadvantages is its short half-life in vivo [28].

Antimalarial agents: Chloroquine/Hydroxychloroquine: In vitro studies have shown its potent antiviral effect against the SARS-CoV-2, preventing viral replication by interfering with the ACE2 receptor. However, chloroquine is a drug with limited use due to its resistance as well as toxicity [29].

Monoclonal antibodies (mAbs): mAbs can neutralize SARS-CoV-1 and inhibit formation of epithelial syncytia through interfering with the binding of some structural proteins with its receptor [30]. In vitro and in vivo studies by multiple groups identified mAbs targeting either SARS-CoV-1, SARS-CoV-2 or MERS-CoV that inhibited viral replication [31,32]. Nevertheless, a limitation for the development of mAbs is the long period of time until their clinical application.

Human convalescent plasma: Convalescent plasma from patients who have recovered from viral infections has been used as immunotherapy to SARS and COVID-19 [33,34]. Studies have suggested that plasma contains high titres of neutralizing antibodies that may suppress viremia if administered early in the course of infection [35].

Vaccines: The best strategy for prevention of new outbreaks of CoVs is the development of a vaccine providing protective active immunity. There are a large number of proposed vaccines against SARS-CoV-2, based on the following strategies: inactivated viruses, live-attenuated viruses, viral vector-based vaccines, subunit vaccines, recombinant proteins and DNA/RNA vaccines. Some of them have been approved for emergency use by the WHO such as Pfizer/BioNtech, Astrazeneca/AZD1222, Janssen/Ad26.COV 2.S, Moderna, Sinopharm and Sinovac-CoronaVac. 


\section{Challenges in Developing CoV Vaccines}

Over the past two decades, new outbreaks of infectious diseases have emerged, e.g., Zika, Ebola, MERS, SARS and now COVID-19. With each new threat there is an urgent need to develop safe and effective vaccines within a short period of time. The effectiveness of a vaccine depends on the properties of antigen recognition, activation, expansion, memory, vaccine trafficking and a multitude of specialist functions of lymphocytes [36]. An ideal vaccine should induce and maintain efficacious concentrations of virus-specific antibodies, as well as specific T-cell immunity, without causing significant adverse effects. Nevertheless, historically vaccine development has always been a slow process, generally taking years to produce a licensed vaccine [37]. Therefore, an ideal production platform should have the following characteristics: speed, low cost and high scalability, while it should demonstrate elicitation of consistent immune responses across pathogens [38]. The use of new technologies such as next-generation sequencing and reverse genetics can help shorten the time of vaccine development [38]. Even so, there are several challenges to overcome for the development of an efficient vaccine against $\mathrm{CoVs}$, regardless of production system and final formulation.

At first, the optimization of the design of the antigen that will act as a potent immunogen is a crucial step to ensure the most efficacious immune response. Based on studies of Respiratory Syncytial Virus (RSV) vaccine development, it seems that the most protective epitopes of the $S$ protein together with a Th1 $\mathrm{T}$ cell response may be key features of a safe SARS-CoV-2 vaccine [39]. Indeed, the S protein of SARS-CoV-2 has been shown to be a promising immunogen to induce protection, so almost all SARS-CoV-2 vaccine candidates, including plant-produced ones currently under development are targeted to this surface protein. Some reports [40] have identified a dimeric form of the receptor-binding domain (RBD) of the $\mathrm{S}$ protein of MERS- $\mathrm{CoV}$ as a potent immunogen due to increased antibody titers compared to the conventional monomeric form. This knowledge could be applied for the development of CoVs vaccines not only against MERS but SARS-CoV-1 and 2 too. However, the debate continues whether the best approach is to include the full-length $S$ protein or only RBD [41,42]. Perhaps incorporating more than one antigen into the vaccine formulation could have a positive effect by extending its immunogenicity. Safety is another primary consideration of any vaccine and previous studies with vaccine candidates for SARS and MERS having raised concerns over exacerbating the humoral response associated with adverse effects $[38,39]$. Hence, testing in a suitable animal model permissive to viral replication and that develops pathologic and clinical features consistent with the human disease is a strictly rigorous step. Another concern is that the duration of immunity has not been determined, so it is uncertain if single-dose vaccines will confer immunity. Some developers of licensed SARS-CoV-2 vaccines such as Moderna and Pfizer have considered adding a third dose to its immunization scheme in order to increase the titers of neutralizing antibodies, thereby ensuring the protective efficacy against SARS-CoV-2 variants. The vaccine formulation including the immunogen plus adjuvant can influence the type of immune response. In the case of vaccines based on subunits or inactivated antigens, the addition of adjuvants for directing the types and magnitude of immune responses is necessary. In pre-clinical $\mathrm{CoV}$ vaccine studies, adjuvants such as aluminum salts, emulsions, and toll-like receptor (TLR) agonists have been used in the vaccine formulations [43]. Among these adjuvants, aluminum salts have been applied in S protein or RBD vaccine formulations which have shown to induce neutralizing antibody production [44,45]; these have been associated with protection against SARS-CoV-2 infection. However, alum lacks the capability to promote the activation of CD4+ and CD8+ T cell responses, which together with the antibody responses provide a protective immunity against the SARS-CoV-2 [46]. Other adjuvants, e.g., emulsion adjuvants and TLR agonists, could play a more favorable role inducing both humoral and cellular immune responses [43]. The formulation can also be associated with the administration route. So far, all implemented or tested vaccines against SARS-CoV-2, regardless of their nature (Table 1), are delivered via intramuscular or intradermal injection. Yet intranasal or inhaled application is considered through mucosal membranes of the 
respiratory tract to activate the mucosa-associated lymphoid tissue (MALT), especially its parts, NALT (Nasal ALT) or BALT (Bronchus ALT), and induce a strong local immune response at the site of the virus invasion [47]. The above described challenges concern all vaccines against SARS and MERS, thus also subunit or VLP-based vaccines (see below) possible to produce in plant systems, but analogously to other vaccines-purified and then administered. In the case of oral vaccines, often identified with plant-derived ones, the challenge itself remains the barrier of GALT (Gut ALT) functioning associated with oral tolerance mechanisms (see Section 5).

Regardless of particular approaches to vaccine development, with the COVID-19 pandemic expanding globally and new mutants of SARS-CoV-2 emerging the progress in vaccine production and availability is highly required. Currently there are at least 68 SARS-CoV-2 vaccines under clinical trials. Studies of other related coronavirus such as SARS and MERS can provide important information on aspects of immunity and protection as well as identify features that merit attention with respect to vaccine safety. Protection against SARS-CoV-2 challenge have been demonstrated in preclinical studies in non-human primates [48-52]. However, more studies are necessary in order to establish both the durability of protection and the vaccine safety. Current efforts in vaccine development against SARS-CoV-2 could provide key answers concerning immune control of COVID-19 infection and possibly against new outbreaks of pathogenic coronaviruses in the future.

\subsection{Approaches for Anti-CoV Vaccines}

Classical vaccines are based on live-attenuated pathogens [53-56], inactivated pathogens $[39,55]$ or only specific fragments of pathogens (subunit vaccines) $[36,57,58]$. However, in recent years new vaccine platforms have been developed with more rapid timelines and with a more easily modifiable antigen design. These systems include viruslike particles (VLPs) [59-62] and vaccines based on DNA [59-61] or RNA, including modRNA-containing naturally modified nucleosides or synthetic nucleoside analogs [60-63].

In Table 1 we summarize advantages/disadvantages of each strategy and present some COVID-19 vaccines made with these technologies.

\subsection{Molecular Farming for Recombinant Protein Expression}

Over the last decades, plant-based expression systems have emerged as a novel platform for the production of recombinant proteins in view of a number of advantages compared to the traditional systems (bacteria, yeast species, insect or mammalian cells and transgenic animals). These advantages include rapid production, high scalability, low cost, safety and the capacity to produce multimeric or glycosylated proteins $[64,65]$. Until now, over 100 recombinant proteins such as human serum proteins, growth regulators, vaccines, cytokines, antibodies and enzymes have been produced in different plant species and several of them have reached the late stages of commercial development [66-68]. Importantly, in 2012 "Elelyso", a recombinant enzyme produced in carrot cells and commercialized by Protalix Biotherapeutics (Karmiel, Israel), was approved by the Food and Drug Administration (FDA) for treatment of Gaucher's disease [69]. Other two products which have been licensed are: (1) the plant made scFV mAb used in the production of a recombinant HBV vaccine in Cuba, and (2) the Newcastle disease virus (NDV) vaccine for poultry approved by the US Department of Agriculture (USDA) [70]. However, there are several vaccines produced by plants currently at the clinical trial phases, e.g., VLP-based vaccines against influenza produced by Medicago Inc. (Quebec City, QC, Canada) [71].

Due to its easy genetic transformation and rapid development, Nicotiana benthamiana and N. tabacum are the two species most commonly used for the expression of recombinant proteins in plants. Nevertheless, there are many cereal crops, fruits, and vegetables such as rice, maize, soybean, lettuce, tomato, carrot, potato, and alfalfa that have also been evaluated in plant molecular farming [72]. Interestingly, the use of edible plants for vaccine production had led to the introduction of the term "edible vaccines". This concept 
evolved through the years into "oral vaccines" obtained via at least some plant material processing and delivered under a controlled regime similar to medicines. Although efficacy of oral vaccines still needs to be improved, these could be considered useful, especially in developing countries thanks to the lower production costs and no specialist equipment or facilities required for their storage and application [73].

Table 1. Overview of Vaccine Production Platforms for COVID-19.

\begin{tabular}{|c|c|c|c|c|}
\hline $\begin{array}{l}\text { Vaccine } \\
\text { Platform }\end{array}$ & Advantages & Disadvantages & Developers (Vaccines) & References \\
\hline Live attenuated & $\begin{array}{l}\text { Mimic natural infection } \\
\text { Long-lasting immunity } \\
\text { Process used for several } \\
\text { licensed human vaccines }\end{array}$ & $\begin{array}{l}\text { Possibility to reverse to } \\
\text { natural form } \\
\text { Contraindicated in } \\
\text { immunocompromised } \\
\text { individuals }\end{array}$ & $\begin{array}{c}\text { Codagenix (COVI-VAC) } \\
\text { Meissa Vaccines, Inc. (MV-014-212) }\end{array}$ & {$[53-61]$} \\
\hline Inactivated & $\begin{array}{l}\text { No replication of the } \\
\text { inactivated pathogen } \\
\text { High stability } \\
\text { Process used for several } \\
\text { licensed human vaccines }\end{array}$ & $\begin{array}{c}\text { Antigen and/or } \\
\text { epitope integrity needs } \\
\text { to be confirmed } \\
\text { Multiple booster doses } \\
\text { are required to obtain } \\
\text { long-term protection }\end{array}$ & $\begin{array}{c}\text { Sinovac (CoronaVac) } \\
\text { Sinopharm (BIBP-CorV) } \\
\text { Osaka University (CovidVax) }\end{array}$ & {$[39,55]$} \\
\hline Subunit & $\begin{array}{l}\text { Non-infectious } \\
\text { Safe }\end{array}$ & $\begin{array}{l}\text { Reduced } \\
\text { immunogenicity, } \\
\text { adjuvants are } \\
\text { often needed }\end{array}$ & $\begin{array}{c}\text { Novavax (NVX-CoV2373) } \\
\text { Sanofi Pasteur (VAT00008) } \\
\text { Instituto Finlay de Vacunas } \\
\text { (Soberana 02) } \\
\text { Kentucky Bioprocessing (KBP-201) }\end{array}$ & {$[36,57,58]$} \\
\hline VLPs & $\begin{array}{c}\text { Multimeric presentation } \\
\text { of antigen } \\
\text { Safe } \\
\text { No viral replication }\end{array}$ & $\begin{array}{l}\text { Purification can be a } \\
\text { limiting factor }\end{array}$ & $\begin{array}{c}\text { Astrazeneca (Vaxzevria) } \\
\text { CanSino Biologics Inc. (Convidicea) } \\
\text { Gamaleya Research Institute (Sputnik V) } \\
\text { Janssen Pharmaceuticals (Ad26.COV2-S) }\end{array}$ & {$[59-62]$} \\
\hline DNA & $\begin{array}{l}\text { Induce both humoral and } \\
\text { cell-mediated immune } \\
\text { responses } \\
\text { Highly scalable }\end{array}$ & Low immunogenicity & $\begin{array}{c}\text { Zydus Cadila (ZyCoV-D) } \\
\text { Inovio Pharmaceuticals (INO-4800) }\end{array}$ & {$[59-61]$} \\
\hline $\begin{array}{c}\text { RNA } \\
\text { and } \\
\text { modRNA }\end{array}$ & $\begin{array}{l}\text { Safe } \\
\text { Low-cost and highly } \\
\text { scalable }\end{array}$ & $\begin{array}{l}\text { Limited experimental } \\
\text { information } \\
\text { Instability }\end{array}$ & $\begin{array}{l}\text { Pfizer/BioNTech (BNT162b2) } \\
\text { Moderna (mRNA-1273) } \\
\text { CureVac AG (CVnCoV) } \\
\text { Imperial College London }\end{array}$ & {$[61-63]$} \\
\hline
\end{tabular}

\section{Plant Transformation Approaches}

The expression methods used in molecular farming are of the stable or transient type. Both methods are being used in the production of antigens for the development of vaccines against COVID-19. The first can be further subdivided into techniques involving Agrobacterium-mediated transformation of the nuclear genome or the biolistic (particle bombardment) method enabling stable modification of nuclear or chloroplast (plastid) genomes, whereas transient expression may be achieved using viral vectors or by infiltration with Agrobacterium carrying dedicated vectors [74]. These expression approaches are summarized in Figure 2.

Stable methods comprise the transgene insertion into a nuclear or chloroplast genome. A majority of the recombinant proteins to date have been produced by nuclear Agrobacterium -mediated transformation, which takes advantage of the bacteria's ability to transfer DNA segments into the host genome, thereby conferring heritable traits to the progeny. Alternatively, although much less frequently, plants are transformed using the biolistic method. However, in both cases the insertion of the transgene via heterologous recombination is random, which can lead to positional effects such as disruption of essential genes, silencing 
and unpredictable levels of expression in obtained transgenic plants [75]. Another concern is the potential risk of genetically modified plants crossing with native species or food crops. These methods have also been used to express recombinant proteins in dry seeds of cereals, which prolongs their half-life since no cold chain is required for their conservation [74]. Additionally, systems based on transgenic plants have a high scale-up capacity and they have been used for the production of many oral vaccines, which may have lower production costs thanks to the fact that the antigen purification process is not necessary [75].

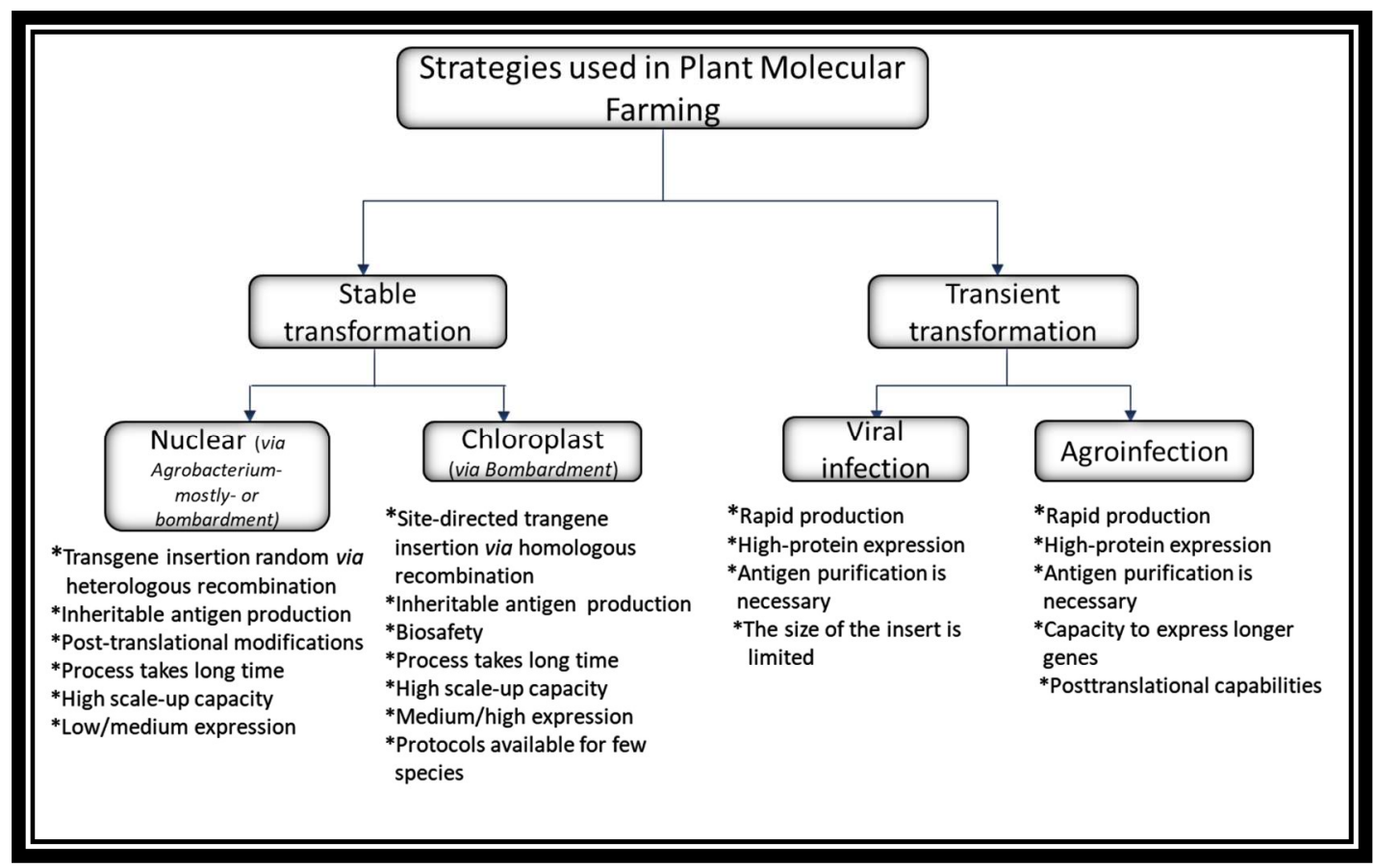

Figure 2. Plant expression systems for biopharmaceutical production.

Alternatively, plastid transformation focuses on expressing the transgenes in chloroplasts. This technology involves the use of a biolistic process in which microparticles of gold or tungsten are coated with foreign DNA, placed on a gene gun and fired at high pressure. Next, the coated DNA travels at a high speed within a vacuum and penetrates into the cells of the targeted plant [76]. Although the biolistic method can be used both for chloroplast and nuclear transformation, the main difference is based on the site-directed insertion of a transgene together with the defined flanking sequences into the plastid genome (plastome) via homologous recombination instead of random integration in the case of the nuclear genome. Besides, transplastomic plants represent additional advantages over transgenic ones, which includes a high recombinant protein yield because of the high number of DNA copies per plastid and then plastids per a vegetal cell, expression of polycistronic genes, natural transgene containment since plastid genes are not usually transmitted through pollen and lack of position effect/gene silencing [75]. The main disadvantage of this system is connected with the fact that it is yet to be adapted for many plant species apart from tobacco and lettuce.

Transient expression systems possess multiple advantages compared with stable methods. These offer rapid and high-protein expression within a few days, hence are considered as a suitable convenient platform, especially for the production of vaccine antigens or antibodies during a pandemic situation. One approach of this system is based on the use of plant viruses as vectors to deliver foreign genes without integration into the plant genome. The main viruses used here are these of the RNA type, such as tobacco mosaic virus (TMV), potato virus X (PVX), alfalfa mosaic virus (AlMV), cucumber mosaic virus (CMV) and cowpea mosaic virus (CPMV) [77]. Several publications have reported the 
successful expression of different immunogenic epitopes as fusions to viral coat proteins. Generally, the limit imposed by 'full virus' vectors on the size of the insert is about $1 \mathrm{~kb}$ [78]. Another, at present more common approach is agroinfiltration-delivery of mixed vectors composed of elements coming from plant viruses and Agrobacterium vectors. This process is in essence an infiltration of whole mature plants with a diluted suspension of Agrobacterium carrying T-DNAs encoding RNA replicons [78]. The infiltration of plants is usually achieved by vacuum infiltration for 10-30 s or by syringe infiltration [79]. This strategy combines the advantages of three biological systems: the speed and expression level/yield of the virus, the transfection efficiency of Agrobacterium, and the posttranslational capabilities and low production cost of plants [78]. Depending on the vector used, the host organism and the initial density of bacteria, the process takes from four to ten days and the expression levels depending on the nature of the gene of interest can reach a yield of up to $5 \mathrm{~g}$ recombinant protein per $\mathrm{kg}$ of fresh leaf biomass or over $50 \%$ of total soluble protein. Additionally, this system has the capacity to express longer genes, up to $2.3 \mathrm{~kb}$ inserts or up to $80 \mathrm{kDa}$ proteins [78].

\subsection{Plant-Made Vaccines against COVID-19 and SARS}

Molecular farming constitutes a consolidated platform for the manufacturing of biopharmaceuticals. At present, this technology is applied for the formulation of injectable or nasal vaccines against different infectious diseases, some of which have entered advanced stages of clinical trials [80]. There are also some examples of plant vaccines directed against COVID-19 and SARS, as summarized in Table 2.

Table 2. Approaches used for the production of plant vaccines directed against CoVs.

\begin{tabular}{|c|c|c|c|}
\hline Approach & $\begin{array}{l}\text { Expressed Antigen/ } \\
\text { Administration Route }\end{array}$ & Relevant Results & References \\
\hline $\begin{array}{l}\text { Nuclear and chloroplast } \\
\text { transformation }\end{array}$ & $\begin{array}{l}\text { 1-658 amino acids of } \\
\text { SARS-CoV-1 S protein }\end{array}$ & $\begin{array}{l}\text { The antigen was successfully expressed in } \\
\text { transgenic tobacco and lettuce as well as in } \\
\text { transplastomic tobacco. }\end{array}$ & [80] \\
\hline Transient expression & $\begin{array}{l}\text { Recombinant SARS-CoV-1 } \\
\text { nucleocapsid } \\
(\mathrm{rN}) \text { protein/intraperitoneal }\end{array}$ & $\begin{array}{l}\text { p19 protein enhanced the transient expression of } \\
\text { rN up to a concentration of } 79 \mu \mathrm{g} \text { per } \mathrm{g} \text { fresh leaf } \\
\text { weight, which induced in mice high levels of } \\
\text { IgG1 and IgG2a. }\end{array}$ & [81] \\
\hline Nuclear expression & $\begin{array}{c}\text { N-terminal } \\
\text { fragment of SARS-CoV S protein } \\
\text { (S1)/oral }\end{array}$ & $\begin{array}{l}\text { S1 protein was expressed in tomato and } \\
\text { low-nicotine tobacco plants, which induced } \\
\text { specific IgA and IgG responses in mice. }\end{array}$ & [82] \\
\hline Transient expression & $\begin{array}{l}\text { Full-length S glycoprotein of } \\
\text { SARS-CoV-2/intramuscular }\end{array}$ & $\begin{array}{c}\text { CoVLP alone or adjuvanted with either CpG1018 } \\
\text { or AS03 suggests that the candidate vaccine is } \\
\text { well-tolerated and immunogenic. Its } \\
\text { immunogenicity, particularly at low doses, is } \\
\text { radically enhanced by the presence } \\
\text { of an adjuvant. }\end{array}$ & [83] \\
\hline Transient expression & $\begin{array}{l}\text { Protein subunit vaccine } \\
\text { based on the SARS-CoV-2 } \\
\text { receptor-binding domain } \\
\text { (RBD)/intramuscular }\end{array}$ & $\begin{array}{l}\text { The vaccine showed a positive result on } \\
\text { stimulation of immune responses in } \\
\text { pre-clinical trials. } \\
\text { Clinical trials results not yet published. }\end{array}$ & [84] \\
\hline Transient expression & $\begin{array}{l}\text { Subunit vaccine combining antigens } \\
\text { derived from the SARS-CoV-2 spike } \\
\text { protein fused to } \\
\text { LicKM/intramuscular }\end{array}$ & $\begin{array}{l}\text { In pre-clinical trials the vaccine (IBIO-201) } \\
\text { stimulated the immune response producing high } \\
\text { titers of neutralizing antibodies. }\end{array}$ & [85] \\
\hline Transient expression & $\begin{array}{l}\text { Subunit vaccine from SARS-CoV-2 } \\
\text { spike protein/injection (no more data } \\
\text { provided) }\end{array}$ & $\begin{array}{l}\text { The vaccine was able to induce antigen-specific } \\
\text { IgG and neutralizing responses as well as } \\
\text { cellular immunity in animals. }\end{array}$ & [86] \\
\hline
\end{tabular}


Li et al. (2006) successfully expressed a segment (sequence encoding amino acids 1-658) of the SARS-CoV-1 S protein in nuclear- and chloroplast-transformed plants. Western blot analysis revealed the expression and accumulation of recombinant $S$ protein in transient and stable transgenic or transplastomic plants [81].

Zheng et al. (2009) produced the SARS-CoV-1 nucleocapsid protein in N. benthamiana plants via transient expression, using the post-transcriptional gene silencing suppressor p19 protein from tomato bushy stunt virus to enhance the expression of recombinant protein. The yield was $79 \mu \mathrm{g}$ per $\mathrm{g}$ fresh leaf weight at three days post infiltration. Moreover, BALB/c assays of mice intraperitoneally vaccinated with a pre-treated plant extract emulsified in Freund's adjuvant induced high levels of IgG1 and IgG2a antibodies and upregulation of IFN- $\gamma$ and IL-10 in splenocytes [82].

Pogrebnyak et al. (2005), expressed the N-terminal fragment of SARS-CoV-1 S protein (S1) in tomato and low-nicotine tobacco plants. The plant-derived antigen was evaluated in vivo, and mice showed significantly increased levels of SARS-CoV-specific IgA after oral ingestion of tomato fruits expressing the S1 protein. Sera of mice parenterally primed with tobacco-derived S1 protein revealed the presence of SARS-CoV-specific IgG as detected by Western blot and ELISA analysis [83].

Ward et al. (2021) reported the first clinical study of a VLP vaccine (CoVLP) using the full-length $S$ glycoprotein produced by transient expression in N. benthamiana plants. The vaccine formulations consisted of CoVLP unadjuvanted or adjuvanted with either CpG 1018 (composed of 227 cytosine-phosphoguanine (CpG) motifs) or AS03 (an oil-inwater emulsion containing tocopherol and squalene). The vaccine formulations were administered in two doses, 21 days apart, to healthy adults 18-55 years of age. Results showed that unadjuvanted CoVLP had the lowest reactogenicity and was recognized by the immune system after the second dose, but the immune responses were modest [84]. In the case of adjuvants incorporated in this study, enhancement of humoral and cellular responses to the $S$ protein and in promoting responses at lower CoVLP doses, AS03 appeared to be more effective than CpG1018.

Kentucky BioProcessing Inc. (KBP) has also been developing a COVID-19 Subunit Vaccine (KBP-201) using the agroinfiltration technique in N. benthamiana plants. KBP reported that its candidate vaccine showed a positive result with stimulation of immune responses in its pre-clinical trials [85]. Currently KBP-201 is under phase 1/2 of clinical trials, the results of which are yet to be published. iBio, a Texas based biotherapeutics company, is developing two potential COVID vaccines, glycosylated IBIO-200 and nonglycosylated IBO-201. The latter is a carrier protein-conjugated subunit vaccine generated by the fusion of the S protein with LicKM, which is an engineered thermostable lichenase enzyme, originally from Clostridium thermocellum. Conjugation of a target antigen with LicKM increases the expression, stability and immunogenicity of the vaccine [86]. In preclinical trials both vaccines were reported to show the ability to stimulate the immune system and they produced anti-spike specific antibodies, with IBIO-201 showing more promising results, with higher levels of neutralizing antibodies against the SARS-CoV-2 virus [85].

Baiya Phytopharm, Thailand, is using the BaiyaPharming ${ }^{\mathrm{TM}}$ technology to express the spike protein in N. benthamiana plants as a COVID-19 vaccine (Baiya SARS-CoV-2 Vax 1). Preclinical results demonstrated the production of neutralizing antibodies in mice and monkeys after two doses of purified protein [87]. Based on these positive results, the company is currently assessing the toxicology and side-effects of the vaccine.

\section{Future Directions for Anti-CoV Plant-Made Vaccines}

The fast spread of SARS-CoV-2 suggests that vaccines will be indispensable to end or at least control this global pandemic. Fortunately, now there are many available technologies showing the potential to fight this virus. In this sense, plant biotechnology offers potential solutions through the development of highly valuable recombinant proteins such as vaccines, antibodies and antiviral peptides. Plants have been used as a platform for the 
production of biopharmaceuticals for more than 30 years, an approach often described as 'molecular farming', which has several advantages over other expression systems, such as economy, scalability and safety. Plant systems can also produce proteins of favorable glycan configurations-either slightly different but tolerable by the human immune system, or easily convertible to human type glycans, or finally-humanized [88].

Of greatest relevance, when transient expression systems are used, is that they can be scaled up rapidly to meet sudden and unforeseen demand, which makes it an ideal platform for the production of vaccines in the case of pandemics such as the one we are currently experiencing. The success of this approach is evidenced by several molecular farming companies that specialize in the development of plant-derived proteins, for example Medicago Inc. (Quebec City, QC, Canada), Agrenvec (Madrid, Spain), Protalix BioTherapeutics (Karmiel, Israel), Diamante (Verona, Italy), ORF Genetics (Kópavogur, Iceland), Fraunhofer (Newark, DE, USA) and Ventria Bioscience/Invitria (Fort Collins, CO, USA). Two strategies that are being developed as a means to address the COVID-19 pandemic are the production of subunit vaccines based on individual proteins or VLPs with multiple copies of SARS-CoV-2 antigens arrayed on their surface. Both strategies have been well-studied in plants and several subunit vaccine candidates have already been obtained [89]. In the case of SARS, a prototype vaccine was manufactured within three weeks after receiving the protein sequences, with up to $200 \mathrm{mg}$ of protein produced per $\mathrm{kg}$ of fresh leaves [83]. At least one company is thought to be developing a COVID-19 vaccine based on the expression of SARS-CoV-2 protein subunits in tobacco plants, namely Kentucky BioProcessing (Owensboro, KY, USA) [85]. As an alternative to subunit vaccines, the development of VLPs has multiple advantages, since the ordered antigen arrangement can trigger even stronger cellular and humoral responses. Medicago Inc. (Quebec City, QC, Canada) has announced the production of VLPs against SARS-CoV-2 by a transient expression system in tobacco plants. This company has estimated the production capacity of 10 million doses per month of VLPs-based vaccines.

VLPs composed of SARS-CoV-2 proteins, mostly S, and produced using the transient expression technology can be considered as the first choice in the use of plant biotechnology to combat COVID-19 pandemics. However, alternatively to VLPs composed by whole or slightly truncated SARS-CoV-2 proteins, only the key virus epitopes, when identified, can potentially be used as vaccine immunogens. In this approach, these epitopes could be covalently or non-covalently attached to carrier VLPs, especially these assembled by HBcAg (Hepatitis B core Antigen) [90,91]. Prominent HBcAg properties of various epitope presentations result in the stability of chimeric 'monoepitopic' VLPs, composed of solely HBc-epitope monomers. Durability of VLPs displaying heterologous epitopes may be further enhanced via the mosaic structure of VLPs. This VLP form makes it possible to reduce steric hindrance in the case of epitopes of particularly large size or specific structure. So far mosaic HBcAg VLPs have been obtained in plant expression systems via the assembly of $\mathrm{HBc}+\mathrm{HBc}$-epitope heterodimers [92]. However, an alternative method may be proposed based on the co-expression of an unmodified HBcAg and HBc-epitope, analogously to heteromultimeric VLPs of the bluetongue virus [93]. Chimeric HBcAg VLPs of both types were produced via transient expression, but also in transgenic or transplastomic plants. Regardless of the expression system and VLP type, displayed epitopes of viral, bacterial and even parasite origin showed proper immunogenicity, e.g., the HBE capsid epitope, the ZIKV E protein domain III (zDIII), M2e of influenza virus, domain- 4 of the anthrax protective antigen (PA-D4) or cysteine protease of liver fluke [94-98]. Hence, considering the current state-of-the-art technology, it can be stated that there is no technological barrier to obtaining plant-produced monoepitopic or mosaic VLPs with a cluster of epitopes as vaccines against a given SARS-CoV-2 variant or even a multivalent vaccine against several variants of the virus or various coronaviruses.

Apart from $\mathrm{HBcAg}$, other VLPs coming from human or animal viruses can also be used as epitope carriers, but to date only some have been produced in plants, e.g., these assembled by S-HBsAg (Small Hepatitis B surface Antigen) or HPV (Human Papilloma 
Virus) L1 protein [99-101]. However, in recent years VLPs derived from plant viruses such as e.g., TMV, CMV or PapMV, (Papaya Mosaic Virus) or PVX, are more and more extensively investigated both as epitope carriers and for other biopharming and nanotechnology purposes [102,103]. Moreover, such VLPs can be safely produced in substantial quantities, due to capacity of massive propagation of plant viruses in suitable hosts [70]. Considerable potential as an epitope carrier is also reported to exist for the oligomeric proteins LTB (heat-labile enterotoxin) and CTB (cholera toxin B), which at the same time act as mucosal adjuvants, as confirmed also in the case of plant-expressed LTB and CTB [104]. The use of carrier platforms may facilitate rapid development of new vaccine variants in response to emerging virus mutants. All these VLPs or oligomers can be used for injection after purification, but prospectively also as vaccines delivered through mucosa, i.e., as intranasal, inhaled or sublingual vaccines (Figure 3).

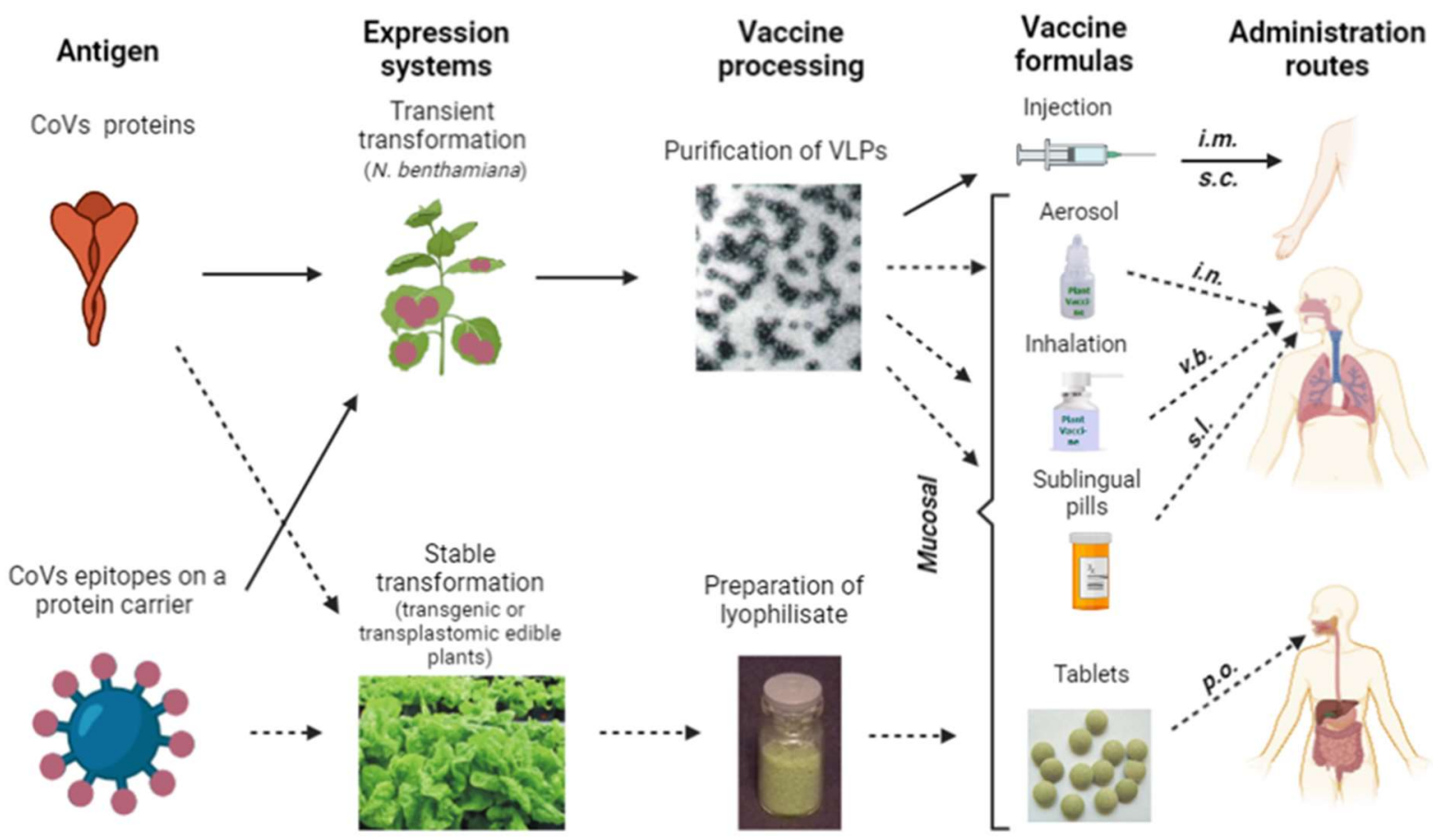

Figure 3. Summary of currently exploited (full arrows) and potential future (dotted arrows) approaches to manufacturing and application of various types of plant-based vaccines against CoVs. Administration routes: i.m.-intramuscular, s.c.-subcutaneous, i.n.—intranasal, v.b.—via bronchi, s.l.—sublingual, p.o.-per os.

Furthermore, since the function of particular parts of MALT such as e.g., NALT or BALT share analogous functioning mechanisms to GALT and they interact with each other, it can be assumed that oral vaccination against SARS-CoV-2 and other coronaviruses would also be developed over time [105,106]. Production of oral vaccines is based on stable antigen expression in transgenic or transplastomic plants and requires only partial tissue processing, usually involving lyophilization [107]. However, development of an appropriate oral administration regime is particularly important. Antigen dosage, frequency of delivery and adjuvants have to be meticulously adjusted to induce efficacious mucosal and systemic responses instead of oral tolerance acquisition [106,108]. Nevertheless, plant-derived oral vaccines were demonstrated to be fully efficacious when applied as boosting doses [109]. Therefore, even in that form they may still be useful at the post-pandemic stage, especially if the SARS-CoV-2 virus becomes a seasonal pathogen. A low-cost plant-derived vaccine would be an advantageous alternative, particularly in developing countries (Figure 3). 


\section{Conclusions}

Pandemics will generate simultaneous demand for vaccines around the world. Therefore, the use of different platforms for the production of safe and effective vaccines is desirable in order to meet global demand. In this sense, the advantages of plant-based platforms such as low cost, speed, scalability, and safety could help to cover the global demand. However, knowledge of the use of plant expression systems for vaccine production should be more widely disclosed to promote their adoption by governments or private companies in prospect to increase the global health; especially in developing and low-income countries. Discussions with global stakeholders about organizing and financing large-scale vaccine manufacturing, procurement, and delivery are required.

Author Contributions: Conceptualization, B.O.-B. and T.P.; investigation, B.O.-B.; writing-original draft preparation, B.O.-B.; writing - review and editing, T.P.; visualization, B.O.-B. and T.P.; supervision, T.P. All authors have read and agreed to the published version of the manuscript.

Funding: This study was funded by the National Science Center, POLS project, No. UMO-2020/37/K/ NZ7/02387.

Acknowledgments: The authors are grateful to Anna Binczarowska, Poznań University of Life Sciences, for careful review and language correction of the manuscript.

Conflicts of Interest: The authors declare that they have no conflicts of interest.

\section{References}

1. Chen, Y.; Liu, Q.; Guo, D. Emerging coronaviruses: Genome structure, replication, and pathogenesis. J. Med. Virol. 2020, 92, 418-423. [CrossRef]

2. Fehr, A.R.; Perlman, S. Coronaviruses: An Overview of Their Replication and Pathogenesis. Methods Mol. Biol. 2015, 1282, 1-23. [CrossRef]

3. Snijder, E.J.; van der Meer, Y.; Zevenhoven-Dobbe, J.; Onderwater, J.J.M.; van der Meulen, J.; Koerten, H.K.; Mommaas, A.M. Ultrastructure and Origin of Membrane Vesicles Associated with the Severe Acute Respiratory Syndrome Coronavirus Replication Complex. J. Virol. 2006, 80, 5927-5940. [CrossRef] [PubMed]

4. Cauchemez, S.; Van Kerkhove, M.D.; Riley, S.; Donnelly, C.A.; Fraser, C.; Ferguson, N.M. Transmission scenarios for middle east respiratory syndrome coronavirus (MERS-CoV) and how to tell them apart. Euro. Surveill. 2013, 18, 20503. [CrossRef]

5. Ludwig, S.; Zarbock, A. Coronaviruses and SARS-CoV-2: A Brief Overview. Anesth. Analg. 2020, 30, 93-96. [CrossRef]

6. Tian, X.; Li, C.; Huang, A.; Xia, S.; Lu, S.; Shi, Z.; Lu, L.; Jiang, S.; Yang, Z.; Wu, Y.; et al. Potent binding of 2019 novel coronavirus spike protein by a SARS coronavirus-specific human monoclonal antibody. Emerg. Microbes Infect. 2020, 9, 382-385. [CrossRef]

7. Drexler, J.F.; Corman, V.M.; Drosten, C. Ecology, evolution and classification of bat coronaviruses in the aftermath of SARS. Antiviral Res. 2014, 101, 45-56. [CrossRef]

8. Prompetchara, E.; Ketloy, C.; Palaga, T. Immune responses in COVID-19 and potential vaccines: Lessons learned from SARS and MERS epidemic. Asian Pac. J. Allergy Immunol. 2020, 38, 1-9. [CrossRef] [PubMed]

9. Weekly Epidemiological Update on COVID-19-30 November 2021. Available online: https://www.who.int/publications/m/ item/weekly-epidemiological-update-on-covid-19---30-November-2021 (accessed on 30 November 2021).

10. Masters, P.S. The molecular biology of coronaviruses. Adv. Virus Res. 2006, 66, 193-292. [PubMed]

11. Ziebuhr, J. The coronavirus replicase. Curr. Top. Microbiol. Immunol. 2005, 287, 57-94. [CrossRef]

12. De Diego, M.L.; Nieto-Torres, J.L.; Jimenez-Guardeño, J.M.; Regla-Nava, J.A.; Castaño-Rodriguez, C.; Fernandez-Delgado, R.; Usera, F.; Enjuanes, L. Coronavirus virulence genes with main focus on SARS-CoV envelope gene. Virus Res. 2014, 194, 124-137. [CrossRef]

13. Nal, B.; Chan, C.; Kien, F.; Siu, L.; Tse, J.; Chu, K.; Kam, J.; Staropoli, I.; Crescenzo-Chaigne, B.; Escriou, N.; et al. Differential maturation and subcellular localization of severe acute respiratory syndrome coronavirus surface proteins S, M and E. J. Gen. Virol. 2005, 86, 1423-1434. [CrossRef] [PubMed]

14. Neuman, B.W.; Kiss, G.; Kunding, A.H.; Bhella, D.; Baksh, M.F.; Connelly, S.; Droese, B.; Klaus, J.P.; Makino, S.; Sawicki, S.G.; et al. A structural analysis of M protein in coronavirus assembly and morphology. J. Struct. Biol. 2011, 174, 11-22. [CrossRef]

15. De Diego, M.L.; Álvarez, E.; Almazán, F.; Rejas, M.T.; Lamirande, E.; Roberts, A.; Shieh, W.-J.; Zaki, S.R.; Subbarao, K.; Enjuanes, L. A Severe Acute Respiratory Syndrome Coronavirus That Lacks the E Gene Is Attenuated In Vitro and In Vivo. J. Virol. 2007, 81, 1701-1713. [CrossRef] [PubMed]

16. Luan, J.; Lu, Y.; Jin, X.; Zhang, L. Spike protein recognition of mammalian ACE2 predicts the host range and an optimized ACE2 for SARS-CoV-2 infection. Biochem. Biophys. Res. Commun. 2020, 526, 165-169. [CrossRef] [PubMed]

17. Hamming, I.; Timens, W.; Bulthuis, M.L.C.; Lely, A.T.; Navis, G.J.; van Goor, H. Tissue distribution of ACE2 protein, the functional receptor for SARS coronavirus. A first step in understanding SARS pathogenesis. J. Pathol. 2004, 203, 631-637. [CrossRef] 
18. Sheahan, T.P.; Sims, A.C.; Graham, R.L.; Menachery, V.D.; Gralinski, L.E.; Case, J.B.; Leist, S.R.; Pyrc, K.; Feng, J.Y.; Trantcheva, I.; et al. Broad-spectrum antiviral GS-5734 inhibits both epidemic and zoonotic coronaviruses. Sci. Transl. Med. 2017, 9, eaal3653. [CrossRef] [PubMed]

19. Gordon, C.J.; Tchesnokov, E.P.; Woolner, E.; Perry, J.K.; Feng, J.Y.; Porter, D.P.; Götte, M. Remdesivir is a direct-acting antiviral that inhibits RNA-dependent RNA polymerase from severe acute respiratory syndrome coronavirus 2 with high potency. J. Biol. Chem. 2020, 295, 6785-6797. [CrossRef]

20. Dong, L.; Hu, S.; Gao, J. Discovering drugs to treat coronavirus disease 2019 (COVID-19). Drug Discov. Ther. 2020, 14, 58-60. [CrossRef]

21. Amawi, H.; Abu Deiab, G.I.; Aljabali, A.A.A.; Dua, K.; Tambuwala, M.M. COVID-19 pandemic: An overview of epidemiology, pathogenesis, diagnostics and potential vaccines and therapeutics. Ther. Deliv. 2020, 11, 245-268. [CrossRef]

22. Chan, J.F.-W.; Yao, Y.; Yeung, M.-L.; Deng, W.; Bao, L.; Jia, L.; Li, F.; Xiao, C.; Gao, H.; Yu, P.; et al. Treatment with lopinavir/ritonavir or interferon- $\beta 1 \mathrm{~b}$ improves outcome of MERS-CoV in a nonhuman primate model of common marmoset. J. Infect. Dis. 2015, 212, 1904-1913. [CrossRef] [PubMed]

23. Chu, C.M.; Cheng, V.C.C.; Hung, I.F.N.; Wong, M.M.L.; Chan, K.H.; Chan, K.S.; Kao, R.Y.T.; Poon, L.L.M.; Wong, C.L.P.; Guan, Y.; et al. Role of lopinavir/ritonavir in the treatment of SARS: Initial virological and clinical findings. Thorax 2004, 59, 252-256. [CrossRef] [PubMed]

24. Khamitov, R.A.; Loginova, S.; Shchukina, V.N.; Borisevich, S.V.; Maksimov, V.A.; Shuster, A. Antiviral activity of arbidol and its derivatives against the pathogen of severe acute respiratory syndrome in the cell cultures. Vopr. Virusol. 2008, 53, 9-13. (In Russian) [PubMed]

25. Xia, S.; Zhu, Y.; Liu, M.; Lan, Q.; Xu, W.; Wu, Y.; Ying, T.; Liu, S.; Shi, Z.; Jiang, S.; et al. Fusion mechanism of 2019-nCoV and fusion inhibitors targeting HR1 domain in spike protein. Cell. Mol. Immunol. 2020, 17, 765-767. [CrossRef] [PubMed]

26. Yuan, K.; Yi, L.; Chen, J.; Qu, X.; Qing, T.; Rao, X.; Jiang, P.; Hu, J.; Xiong, Z.; Nie, Y.; et al. Suppression of SARS-CoV entry by peptides corresponding to heptad regions on spike glycoprotein. Biochem. Biophys. Res. Commun. 2004, 319, 746-752. [CrossRef]

27. Zhu, Y.; Yu, D.; Yan, H.; Chong, H.; He, Y. Design of Potent Membrane Fusion Inhibitors against SARS-CoV-2, an Emerging Coronavirus with High Fusogenic Activity. J. Virol. 2020, 94, e00635-20. [CrossRef]

28. Vanpatten, S.; He, M.; Altiti, A.; Cheng, K.F.; Ghanem, M.H.; Al-Abed, Y. Evidence supporting the use of peptides and peptidomimetics as potential SARS-CoV-2 (COVID-19) therapeutics. Future Med. Chem. 2020, 12, 1647-1656. [CrossRef]

29. Savarino, A.; Boelaert, J.R.; Cassone, A.; Majori, G.; Cauda, R. Effects of chloroquine on viral infections: An old drug against today's diseases? Lancet Infect. Dis. 2003, 3, 722-727. [CrossRef]

30. Duan, J.; Yan, X.; Guo, X.; Cao, W.; Han, W.; Qi, C.; Feng, J.; Yang, D.; Gao, G.; Jin, G. A human SARS-CoV neutralizing antibody against epitope on $\mathrm{S} 2$ protein. Biochem. Biophys. Res. Commun. 2005, 333, 186-193. [CrossRef]

31. Pascal, K.E.; Coleman, C.M.; Mujica, A.O.; Kamat, V.; Badithe, A.; Fairhurst, J.; Hunt, C.; Strein, J.; Berrebi, A.; Sisk, J.M.; et al. Preand postexposure efficacy of fully human antibodies against Spike protein in a novel humanized mouse model of MERS-CoV infection. Proc. Natl. Acad. Sci. USA 2015, 112, 8738-8743. [CrossRef]

32. Zhu, Z.; Chakraborti, S.; He, Y.; Roberts, A.; Sheahan, T.; Xiao, D.; Hensley, L.E.; Prabakaran, P.; Rockx, B.; Sidorov, I.A.; et al Potent cross-reactive neutralization of SARS coronavirus isolates by human monoclonal antibodies. Proc. Natl. Acad. Sci. USA 2007, 104, 12123-12128. [CrossRef] [PubMed]

33. Cheng, Y.; Wong, R.; Soo, Y.O.Y.; Wong, W.S.; Lee, C.K.; Ng, M.H.L.; Chan, P.; Wong, K.C.; Leung, C.B.; Cheng, G. Use of convalescent plasma therapy in SARS patients in Hong Kong. Eur. J. Clin. Microbiol. Infect. Dis. 2005, 24, 44-46. [CrossRef] [PubMed]

34. Li, H.; Wang, Y.M.; Xu, J.Y.; Cao, B. Potential antiviral therapeutics for 2019 Novel Coronavirus. Chin. J. Tuberc. Respir. Dis. 2020, 43, E002. (In Chinese) [CrossRef]

35. Weiss, S.R.; Navas-Martin, S. Coronavirus Pathogenesis and the Emerging Pathogen Severe Acute Respiratory Syndrome Coronavirus. Microbiol. Mol. Biol. Rev. 2005, 69, 635-664. [CrossRef]

36. Afrough, B.; Dowall, S.; Hewson, R. Emerging viruses and current strategies for vaccine intervention. Clin. Exp. Immunol. 2019, 196, 157-166. [CrossRef]

37. Gouglas, D.; Thanh Le, T.; Henderson, K.; Kaloudis, A.; Danielsen, T.; Hammersland, N.C.; Robinson, J.M.; Heaton, P.M.; Røttingen, J.A. Estimating the cost of vaccine development against epidemic infectious diseases: A cost minimisation study. Lancet Glob. Health 2018, 6, e1386-e1396. [CrossRef]

38. Hunter, D.J. Developing Covid-19 vaccines at pandemic speed. N. Engl. J. Med. 2020, 31, 1969-1973.

39. Diamond, M.S.; Pierson, T.C. The Challenges of Vaccine Development against a New Virus during a Pandemic. Cell Host Microbe 2020, 27, 699-703. [CrossRef]

40. Dai, L.; Zheng, T.; Xu, K.; Han, Y.; Xu, L.; Huang, E.; An, Y.; Cheng, Y.; Li, S.; Liu, M.; et al. A universal design of betacoronavirus vaccines against COVID-19, MERS, and SARS. Cell. 2020, 182, 722-733. [CrossRef] [PubMed]

41. Dagotto, G.; Yu, J.; Barouch, D.H. Approaches and Challenges in SARS-CoV-2 Vaccine Development. Cell Host Microbe 2020, 28, 364-370. [CrossRef]

42. Ahmed, S.F.; Quadeer, A.A.; McKay, M.R. Preliminary identification of potential vaccine targets for the COVID-19 Coronavirus (SARS-CoV-2) Based on SARS-CoV Immunological Studies. Viruses 2020, 12, 254. [CrossRef] 
43. Liang, Z.; Zhu, H.; Wang, X.; Jing, B.; Li, Z.; Xia, X.; Sun, H.; Yang, Y.; Zhang, W.; Shi, L.; et al. Adjuvants for coronavirus vaccines. Front. Immunol. 2020, 11, 2896-2905. [CrossRef]

44. Coleman, C.M.; Liu, Y.V.; Mu, H.; Taylor, J.K.; Massare, M.; Flyer, D.C.; Smith, G.E.; Frieman, M.B. Purified coronavirus spike protein nanoparticles induce coronavirus neutralizing antibodies in mice. Vaccine. 2014, 32, 3169-3174. [CrossRef]

45. Lan, J.; Deng, Y.; Chen, H.; Lu, G.; Wang, W.; Guo, X.; Lu, Z.; Gao, G.F.; Tan, W. Tailoring subunit vaccine immunity with adjuvant combinations and delivery routes using the Middle East respiratory coronavirus (MERS-CoV) receptor-binding domain as an antigen. PLOS ONE 2014, 9, e112602. [CrossRef]

46. Moderbacher, C.R.; Ramirez, S.I.; Dan, J.M.; Grifoni, A.; Hastie, K.M.; Weiskopf, D.; Belanger, S.; Abbott, R.K.; Kim, C.; Choi, J.; et al. Antigen-specific adaptive immunity to SARS-CoV-2 in acute COVID-19 and associations with age and disease severity. Cell 2020, 183, 996-1012. [CrossRef] [PubMed]

47. An, D.; Li, K.; Rowe, D.K.; Diaz, M.C.H.; Griffin, E.F.; Beavis, A.C.; Johnson, S.K.; Padykula, I.; Jones, C.A.; Briggs, K.; et al Protection of K18-hACE2 mice and ferrets against SARS-CoV-2 challenge by a single-dose mucosal immunization with a parainfluenza virus 5-based COVID-19 vaccine. Sci. Adv. 2021, 7, eabi5246. [CrossRef] [PubMed]

48. Corbett, K.S.; Flynn, B.; Foulds, K.E.; Francica, J.R.; Boyoglu-Barnum, S.; Werner, A.P.; Flach, B.; O'Connell, S.; Bock, K.W.; Minai, M.; et al. Evaluation of the mRNA-1273 Vaccine against SARS-CoV-2 in Nonhuman Primates. N. Engl. J. Med. 2020, 383, 1544-1555. [CrossRef] [PubMed]

49. Wang, H.; Zhang, Y.; Huang, B.; Deng, W.; Quan, Y.; Wang, W.; Xu, W.; Zhao, Y.; Li, N.; Zhang, J.; et al. Development of an Inactivated Vaccine Candidate, BBIBP-CorV, with Potent Protection against SARS-CoV-2. Cell 2020, 182, 713-721.e9. [CrossRef]

50. Mercado, N.B.; Zahn, R.; Wegmann, F.; Loos, C.; Chandrashekar, A.; Yu, J.; Liu, J.; Peter, L.; McMahan, K.; Tostanoski, L.H.; et al. Single-shot Ad26 vaccine protects against SARS-CoV-2 in rhesus macaques. Nature 2020, 586, 583-588. [CrossRef]

51. Van Doremalen, N.; Lambe, T.; Spencer, A.; Belij-Rammerstorfer, S.; Purushotham, J.N.; Port, J.R.; Avanzato, V.A.; Bushmaker, T.; Flaxman, A.; Ulaszewska, M.; et al. ChAdOx1 nCoV-19 vaccine prevents SARS-CoV-2 pneumonia in rhesus macaques. Nature 2020, 586, 578-582. [CrossRef]

52. Yu, J.; Tostanosk, L.H.; Peter, L.; Mercad, N.B.; McMahan, K.; Mahrokhia, S.H.; Nkolol, J.P.; Liu, J.; Li, Z.; Chandrashekar, A.; et al. DNA vaccine protection against SARS-CoV-2 in rhesus macaques. Science 2020, 369, 806-811. [CrossRef] [PubMed]

53. Hajj Hussein, I.; Chams, N.; Chams, S.; El Sayegh, S.; Badran, R.; Raad, M.; Gerges-Geagea, A.; Leone, A.; Jurjus, A. Vaccines Through Centuries: Major Cornerstones of Global Health. Front. Public Health 2015, 3, 269. [CrossRef] [PubMed]

54. Pulendran, B.; Ahmed, R. Immunological mechanisms of vaccination. Nat. Immunol. 2011, 12, 509-517. [CrossRef]

55. Vetter, V.; Denizer, G.; Friedland, L.R.; Krishnan, J.; Shapiro, M. Understanding modern-day vaccines: What you need to know. Ann. Med. 2018, 50, 110-120. [CrossRef] [PubMed]

56. Gillim-Ross, L.; Subbarao, K. Emerging respiratory viruses: Challenges and vaccine strategies. Clin. Microbiol. Rev. 2006, 19, 614-636. [CrossRef]

57. Droppa-Almeida, D.; Franceschi, E.; Padilha, F.F. Immune-informatic analysis and design of peptide vaccine from multi-epitopes against Corynebacterium pseudotuberculosis. Bioinform. Biol. Insights 2018, 12, 25-29. [CrossRef]

58. Rappuoli, R.; Pizza, M.; Del Giudice, G.; De Gregorio, E. Vaccines, new opportunities for a new society. Proc. Natl. Acad. Sci. USA 2014, 111, 12288-12293. [CrossRef] [PubMed]

59. Zhang, L.F.; Zhou, J.; Chen, S.; Cai, L.L.; Bao, Q.Y.; Zheng, F.Y.; Lu, J.Q.; Padmanabha, J.; Hengst, K.; Malcolm, K.; et al. HPV6b virus like particles are potent immunogens without adjuvant in man. Vaccine 2000, 18, 1051-1058. [CrossRef]

60. García-Sastre, A.; Mena, I. Novel vaccine strategies against emerging viruses. Curr. Opin. Virol. 2013, 3, 210-216. [CrossRef]

61. Wallis, J.; Shenton, D.P.; Carlisle, R.C. Novel approaches for the design, delivery and administration of vaccine technologies. Clin. Exp. Immunol. 2019, 196, 189-204. [CrossRef]

62. Maslow, J.N. Vaccine development for emerging virulent infectious diseases. Vaccine 2017, 35, 5437-5443. [CrossRef] [PubMed]

63. Roncati, L.; Corsi, L. Nucleoside-modified messenger RNA COVID-19 vaccine platform. J. Med. Virol. 2021, 93, 4054-4057. [CrossRef] [PubMed]

64. Obembe, O.O.; Popoola, J.O.; Leelavathi, S.; Reddy, S.V. Advances in plant molecular farming. Biotechnol. Adv. 2011, 29, $210-222$. [CrossRef]

65. Twyman, R.M.; Stoger, E.; Schillberg, S.; Christou, P.; Fischer, R. Molecular farming in plants: Host systems and expression technology. Trends Biotechnol. 2003, 21, 570-578. [CrossRef] [PubMed]

66. Lienard, D. Pharming and transgenic plants. Biotechnol. Annu. Rev. 2007, 13, 115-147.

67. Giddings, G. Transgenic plants as protein factories. Curr. Opin. Biotechnol. 2001, 12, 450-454. [CrossRef]

68. Fischer, R.; Emans, N. Molecular farming of pharmaceutical proteins. Transgenic Res. 2000, 9, 279-299. [CrossRef]

69. Tekoah, Y.; Shulman, A.; Kizhner, T.; Ruderfer, I.; Fux, L.; Nataf, Y.; Bartfeld, D.; Ariel, T.; Gingis-Velitski, S.; Hanania, U.; et al. Large-scale production of pharmaceutical proteins in plant cell culture-the protalix experience. Plant Biotechnol. J. 2015, 13, 1199-1208. [CrossRef]

70. Naderi, S.; Baratali, F. Overview of Plant-based Vaccines. Res. J. Fish. Hydrobiol. 2015, 10, 275-289.

71. Ward, B.J.; Makarkov, A.; Séguin, A.; Pillet, S.; Trépanier, S.; Dhaliwall, J.; Libman, M.D.; Vesikari, T.; Landry, N. Efficacy, immunogenicity, and safety of a plant-derived, quadrivalent, virus-like particle influenza vaccine in adults (18-64 years) and older adults ( $\geq 65$ years): Two multicentre, randomised phase 3 trials. Lancet 2020, 396, 1491-1503. [CrossRef] 
72. Shanmugaraj, B.; Bulaon, C.J.I.; Phoolcharoen, W. Plant molecular farming: A viable platform for recombinant biopharmaceutical production. Plants 2020, 9, 842. [CrossRef]

73. Sartaj Sohrab, S.; Suhail, M.; Kamal, M.A.; Husen, A.; Azhar, E.I. Recent Development and Future Prospects of Plant-Based Vaccines. Curr. Drug Metab. 2017, 18, 831-841. [CrossRef] [PubMed]

74. Moon, K.B.; Park, J.S.; Park, Y.I.; Song, I.J.; Lee, H.J.; Cho, H.S.; Jeon, J.H.; Kim, H.S. Development of systems for the production of plant-derived biopharmaceuticals. Plants 2020, 9, 30. [CrossRef] [PubMed]

75. Rosales-Mendoza, S.; Márquez-Escobar, V.A.; González-Ortega, O.; Nieto-Gómez, R.; Arévalo-Villalobos, J.I. What does plantbased vaccine technology offer to the fight against COVID-19? Vaccines 2020, 8, 183. [CrossRef]

76. Horn, M.E.; Woodard, S.L.; Howard, J.A. Plant molecular farming: Systems and products. Plant Cell Rep. 2004, 22, 711-720. [CrossRef]

77. Laere, E.; Ling, A.P.K.; Wong, Y.P.; Koh, R.Y.; Mohd Lila, M.A.; Hussein, S. Plant-based vaccines: Production and challenges. J. Bot. 2016, 2016, 4928637. [CrossRef]

78. Gleba, Y.; Klimyuk, V.; Marillonnet, S. Magnifection-A new platform for expressing recombinant vaccines in plants. Vaccine 2005, 23, 2042-2048. [CrossRef] [PubMed]

79. Fujiki, M.; Kaczmarczyk, J.F.; Yusibov, V.; Rabindran, S. Development of a new cucumber mosaic virus-based plant expression vector with truncated 3a movement protein. Virology 2008, 381, 136-142. [CrossRef]

80. COVID-19 Vaccine Tracker and Landscape. Available online: https://www.who.int/publications/m/item/draft-landscape-ofcovid-19-candidate-vaccines (accessed on 30 November 2021).

81. Li, H.Y.; Ramalingam, S.; Chye, M.L. Accumulation of recombinant SARS-CoV spike protein in plant cytosol and chloroplasts indicate potential for development of plant-derived oral vaccines. Exp. Biol. Med. 2006, 231, 1346-1352. [CrossRef]

82. Zheng, N.; Xia, R.; Yang, C.; Yin, B.; Li, Y.; Duan, C.; Liang, L.; Guo, H.; Xie, Q. Boosted expression of the SARS-CoV nucleocapsid protein in tobacco and its immunogenicity in mice. Vaccine 2009, 27, 5001-5007. [CrossRef] [PubMed]

83. Pogrebnyak, N.; Golovkin, M.; Andrianov, V.; Spitsin, S.; Smirnov, Y.; Egolf, R.; Koprowski, H. Severe Acute Respiratory Syndrome (SARS) S Protein Production in Plants. Proc. Natl. Acad. Sci. USA 2005, 102, 9062-9067. [CrossRef]

84. Ward, B.J.; Gobeil, P.; Séguin, A.; Atkins, J.; Boulay, I.; Charbonneau, P.Y.; Couture, M.; D’Aoust, M.A.; Dhaliwall, J.; Finkle, C.; et al. Phase 1 randomized trial of a plant-derived virus-like particle vaccine for COVID-19. Nat. Med. 2021, 27, 1071-1078. [CrossRef]

85. Kumar, A.U.; Kadiresen, K.; Gan, W.C.; Ling, A.P.K. Current updates and research on plant-based vaccines for coronavirus disease 2019. Clin. Exp. Vaccine Res. 2021, 10, 13-23. [CrossRef]

86. Maharjan, P.M.; Choe, S. Plant-based COVID-19 vaccines: Current status, design, and development strategies of candidate vaccines. Vaccines 2021, 9, 992. [CrossRef] [PubMed]

87. Shanmugaraj, B.; Siriwattananon, K.; Malla, A.; Phoolcharoen, W. Potential for developing plant-derived candidate vaccines and biologics against emerging coronavirus infections. Pathogens 2021, 10, 1051. [CrossRef]

88. Yusibov, V.; Kushnir, N.; Streatfield, S.J. Antibody Production in Plants and Green Algae. Annu. Rev. Plant Biol. 2016, 67, 669-701. [CrossRef]

89. Rybicki, E.P. Plant molecular farming of virus-like nanoparticles as vaccines and reagents. WIREs Nanomed. Nanobiotechnol. 2020, 12, e1587. [CrossRef] [PubMed]

90. Blokhina, E.A.; Kuprianov, V.V.; Stepanova, L.A.; Tsybalova, L.M.; Kiselev, O.I.; Ravin, N.V.; Skryabin, K.G. A molecular assembly system for presentation of antigens on the surface of HBc virus-like particles. Virology 2013, 435, 293-300. [CrossRef] [PubMed]

91. Pumpens, P.; Grens, E. The true story and advantages of the famous Hepatitis B virus core particles. Mol. Biol. 2016, 50, 489-509. [CrossRef]

92. Stephen, S.L.; Beales, L.; Peyret, H.; Roe, A.; Stonehouse, N.J.; Rowlands, D.J. Recombinant expression of tandem-HBc virus-like particles (VLPs). Methods Mol. Biol. 2018, 1776, 97-123. [CrossRef]

93. Thuenemann, E.C.; Meyers, A.E.; Verwey, J.; Rybicki, E.P.; Lomonossoff, G.P. A method for rapid production of heteromultimeric protein complexes in plants: Assembly of protective bluetongue virus-like particles. Plant Biotechnol. J. 2013, 11, 839-846. [CrossRef] [PubMed]

94. Zahmanova, G.; Mazalovska, M.; Takova, K.; Toneva, V.; Minkov, I.; Peyret, H.; Lomonossoff, G. Efficient production of chimeric hepatitis b virus-like particles bearing an epitope of hepatitis e virus capsid by transient expression in Nicotiana benthamiana. Life 2021, 11, 64. [CrossRef] [PubMed]

95. Yang, M.; Lai, H.; Sun, H.; Chen, Q. Virus-like particles that display Zika virus envelope protein domain III induce potent neutralizing immune responses in mice. Sci. Rep. 2017, 7, 7679. [CrossRef]

96. Ravin, N.V.; Kotlyarov, R.Y.; Mardanova, E.S.; Kuprianov, V.V.; Migunov, A.I.; Stepanova, L.A.; Tsybalova, L.M.; Kiselev, O.I.; Skryabin, K.G. Plant-produced recombinant influenza vaccine based on virus-like HBc particles carrying an extracellular domain of M2 protein. Biochemistry 2012, 77, 33-40. [CrossRef] [PubMed]

97. Bandurska, K.; Brodzik, R.; Spitsin, S.; Kohl, T.; Portocarrero, C.; Smirnov, Y.; Pogrebnyak, N.; Sirko, A.; Koprowski, H.; Golovkin, M. Plant-produced hepatitis B core protein chimera carrying anthrax protective antigen domain-4. Hybridoma 2008, 27, $241-247$. [CrossRef] [PubMed] 
98. Kesik-Brodacka, M.; Lipiec, A.; Kozak Ljunggren, M.; Jedlina, L.; Miedzinska, K.; Mikolajczak, M.; Plucienniczak, A.; Legocki, A.B.; Wedrychowicz, H. Immune response of rats vaccinated orally with various plant-expressed recombinant cysteine proteinase constructs when challenged with Fasciola hepatica metacercariae. PLoS Negl. Trop. Dis. 2017, 11, e0005451. [CrossRef]

99. Qian, B.; Shen, H.; Liang, W.; Guo, X.; Zhang, C.; Wang, Y.; Li, G.; Wu, A.; Cao, K.; Zhang, D. Immunogenicity of recombinant hepatitis B virus surface antigen fused with preS1 epitopes expressed in rice seeds. Transgenic Res. 2008, 17, 621-631. [CrossRef]

100. Matić, S.; Rinaldi, R.; Masenga, V.; Noris, E. Efficient production of chimeric Human papillomavirus 16 L1 protein bearing the M2e influenza epitope in Nicotiana benthamiana plants. BMC Biotechnol. 2011, 11, 106. [CrossRef]

101. Mohammadzadeh, S.; Roohvand, F.; Memarnejadian, A.; Jafari, A.; Ajdary, S.; Salmanian, A.H.; Ehsani, P. Co-expression of hepatitis C virus polytope-HBsAg and p19-silencing suppressor protein in tobacco leaves. Pharm. Biol. 2016, 54, 465-473. [CrossRef]

102. Balke, I.; Zeltins, A. Use of plant viruses and virus-like particles for the creation of novel vaccines. Adv. Drug Deliv. Rev. 2019, 145, 119-129. [CrossRef]

103. Ibrahim, A.; Odon, V.; Kormelink, R. Plant viruses in plant molecular pharming: Toward the use of enveloped viruses. Front. Plant Sci. 2019, 10, 803. [CrossRef]

104. Ríos-Huerta, R.; Monreal-Escalante, E.; Govea-Alonso, D.O.; Angulo, C.; Rosales-Mendoza, S. Expression of an immunogenic LTB-based chimeric protein targeting Zaire ebolavirus epitopes from GP1 in plant cells. Plant Cell Rep. 2017, 36, 355-365. [CrossRef] [PubMed]

105. Randall, T.D. Bronchus-Associated Lymphoid Tissue (BALT). In Structure and Function, 1st ed.; Elsevier Inc.: Amsterdam, The Netherlands, 2010; Volume 107.

106. Pabst, R. Mucosal vaccination by the intranasal route. Nose-associated lymphoid tissue (NALT)-Structure, function and species differences. Vaccine 2015, 33, 4406-4413. [CrossRef]

107. Vela Ramirez, J.E.; Sharpe, L.A.; Peppas, N.A. Current state and challenges in developing oral vaccines. Adv. Drug Deliv. Rev. 2017, 114, 116-131. [CrossRef] [PubMed]

108. Rezende, R.M.; Weiner, H.L. History and mechanisms of oral tolerance. Semin. Immunol. 2017, 30, 3-11. [CrossRef]

109. Pniewski, T.; Milczarek, M.; Wojas-Turek, J.; Pajtasz-Piasecka, E.; Wietrzyk, J.; Czyż, M. Plant lyophilisate carrying S-HBsAg as an oral booster vaccine against HBV. Vaccine 2018, 36, 6070-6076. [CrossRef] [PubMed] 